\title{
The Right to Work and the Right to Develop One's Capabilities
}

\begin{abstract}
I understand the claim that there is a right to work as the claim that involuntary unemployment is an injustice that requires of justice enforcement institutions to stop it. I argue that in present conditions of high productivity it is more consistent with the liberal tradition to proclaim a right to develop one's capabilities than a right to work. The steps of my argument are: (1) An important though not the only reason for considering unemployment unjust has been what I call the Promethean idea of society. (2) The Promethean idea is implied by the liberal idea of rights. (3) There are two conceptions of the Promethean idea, the centralist and the autonomous one. (4) Only the latter is acceptable. (5) Involuntary unemployment is unjust even if the dole is decently high. (6) The injustice of unemployment can be stopped only by institutions that enable everyone to use their capabilities in realizing the Promethean idea. (7) One such institution is basic income. (8) As employment is not necessary for survival, we should replace the right to work with a right to develop one's capabilities.
\end{abstract}

\section{A Plea to Replace the Right to Work with a More Original Right}

Let me preface my investigation with some introductory remarks. The first thing to state in a discussion of the right to work is how curious a conception it is. The Universal Declaration of Human Rights proclaims: "Everyone has the right to work." But as it makes clear by the explanation that follows these words, the right to work it proclaims is a right to find an adequate job: "Everyone has the right to work, to free choice of employment, to just and favorable conditions of work and to protection against unemployment."1

So the right to work would better be called a right to employment or, as the activities of the employed are better called labor than work, a right to labor. As to the concept of a right, I presuppose that the recognition of someone's right to $\mathrm{p}$ is the ascription of a duty of justice enforcement institutions to secure $\mathrm{p}$ for

1 Article 23.1. As Article 1(2) of the German Grundgesetz appeals to the human rights as the basis of German legislation ("Das Deutsche Volk bekennt sich [...] zu unverletzlichen und unveräußerlichen Menschenrechten als Grundlage jeder menschlichen Gemeinschaft, des Friedens und der Gerechtigkeit in der Welt") the right to work proclaimed by the Universal Declaration of Human Rights can be presumed valid in Germany. 
him..$^{2}$ Hence, to proclaim my right to labor implies the duty of justice to secure labor for me. But labor is nothing we like to do if it was not for the money earned by labor, and it is odd to demand to secure someone a disliked activity. Rather than protecting us against the evil of unemployment by a right to labor, we should protect us against the social causes that make unemployment an evil by a right to a life without the coercion of employment if productivity allows for this. True, it is reasonable to proclaim a right to labor if it is injustice to be without employment and we cannot change the social conditions that make unemployment unjust. But we can change them, as I'll try to show.

Now, it is not an accident that what in fact is only a right to employment or labor has been given the more sonorous title of a right to work. By using this title appeal is made to ideas of a specific nobility of work. Such an appeal is also made in hypocritical phrases like the German Arbeit adelt, 'work ennobles the soul', and most atrociously in the words put over the gate of Auschwitz that greeted its victims, Arbeit macht frei, 'work liberates'. Yet, as hypocrisy is a tribute paid to virtue, such uses are possible only because there is a rational core in the idea that work, unlike labor or employment, has a quality that justifies the claim everyone has a right to it. The rational core are these ideas: only by the work of adapting nature, understood as the preconditions of human existence, to human capabilities can human beings become what they are; such work can be performed only in cooperation; exclusion from this cooperative work is injustice. These ideas are inseparable from both socialism and liberalism.

Therefore, the right to live without the coercion of employment that should replace the right to work must be conceived in a way that cooperation in adapting nature to human capabilities is furthered rather than hindered. To conceive it thus we must look closer at the rational core of the ideas of the nobility of work. This core has been developed in what I call the Promethean venture, an idea that inspired poets and philosophers though today it is discredited. But we can neither understand why the right to work has been proclaimed nor what we should replace this right with unless we take account of it.

\section{The Argument of Interaction}

A right to work which in fact is a right to employment can be plausibly assumed only if unemployment is not only unpleasant (because of the lack of money it entails) but also unjust. How can we assume that it is? Suppose the unemployed get an unemployment compensation that is less than their salary but sufficient for a decent life. Would this imply that unemployment is just? My thesis is that even a decent dole does not make involuntary unemployment just. I see two reasons for its injustice. I'll concentrate on what I think is the more interesting one and call it the argument of interaction.

\footnotetext{
${ }^{2}$ I follow the tradition of Wesley Newcomb Hohfeld. Hohfeld defined the paradigm of rights, claim rights, by the concept of duty ( $\mathrm{A}$ has a claim right against $\mathrm{B}$ that $\mathrm{B} \mathrm{p}$ iff $\mathrm{B}$ has a duty against $\mathrm{A}$ that $\mathrm{B}$ ) ) and presumed the existence of justice enforcement institutions. Cp. Hohfeld 1946.
} 
It is an argument inspired by an idea that harks back to Marx and Descartes and more ancient thinkers. ${ }^{3}$ It looks a little obsolete. It assumes, first, a nonnormative way to look at society. This way consists of relating what happens in society to its interaction with its natural and cultural environment, with all the conditions a society finds as something given that form society but to which it can react, thus changing them and being again changed by its reaction to them. I'll subsume these preconditions under the concept of nature although they include history. It is an interaction performed in many spheres, in politics, science, arts and other kinds of activities, but in a particularly momentous way in economy, the activities by which a society produces what it consumes. All of them have started from conditions people did not choose and had to adapt to and aim at a state that leave human capabilities as much opportunity to flourish as possible. Second, the argument assumes a normative principle, namely, that everyone has a right to participate in this interaction, either equally or according to their talents; we need not decide in which way. Its consequence for the question of whether unemployment is unjust is obvious. As the unemployed are excluded from this interaction as far as it occurs in economy, unemployment is unjust.

Before considering objections to the interaction argument, consider its two parts. Its non-normative assumption is the idea that any society interacts with its given environment. Taken for itself, this assumption puts our view of society in a certain light, but it can hardly be denied. We may even say it is trivial and in any case incapable of showing that involuntary unemployment is unjust even though the unemployed get a decent dole. This follows only if we accept the obviously non-trivial normative idea that presupposes the rather trivial descriptive idea of an interaction. This is the idea that the interaction is a process all members of society have a right to participate in or to codetermine. What is this normative idea based on?

\section{The Promethean and the Liberal Normative Premises of the Interaction Argument}

It is based on two parts, the Promethean idea and the liberal proviso.

The Promethean idea is that the interaction is a process that people should determine rather than be determined by. This idea has been articulated, though not sufficiently, in Descartes' idea that people should become "quasi masters and possessors of nature" and Marx's idea of labor as the metabolism between mankind and nature. It assumes that mankind can and ought to become an agent that stops being the result of conditions it has been created by and starts transforming its dependency into a relation in which it increasingly determi-

\footnotetext{
3 Marx implies this idea when he says that "labour [...] is an eternal natural necessity to mediate the metabolism between man and nature, hence human life" (Marx 1971, 57, my translation; there are a lot of similar passages in Marx's writings) and in contemporary literature on ecology. Descartes follows it in his hope that men can become "quasi masters and possessors of nature" (Discours de la méthode, sixième partie). The idea is also implied or suggested by Cicero's view, influenced by the Stoa, that mankind is united by their common power of reason to societas or fellowship; cp. On Duties I 11-14, 6.
} 
nes the conditions it has been determined by. I'll call this transformation the Promethean venture.

The liberal proviso is that whatever is done in the name of mankind must be done in a way every human being can participate in. It requires of the Promethean venture, as it claims to act in the name of mankind, that everyone is codetermining it. In fact, people who are not participating in the process will be determined by those determining the process. Hence, the Promethean venture can be realized only if it conforms to the liberal proviso.

Let us delay considering whether we can agree with the Promethean idea and ask for the reason of the liberal proviso. It is an equality condition that is inseparable from the central idea of liberalism, that of rights. The liberal idea of rights has been most efficiently formulated by Locke and Kant. It says every rational being has an equal claim on deciding on their own life or, negatively expressed, no such being has a privilege in deciding on other people. ${ }^{4}$ It is rooted in two premises: 'abilities imply entitlements' and 'equal abilities imply equal entitlements'. Hence, if creatures have the ability of deciding on their life in a way that takes account of the same ability and similar interests of creatures with the same ability, they are entitled to use their ability; hence, have a right to decide on their life. And if they do not differ in this ability, they have an equal right to do so; hence, the basic right of liberty is conditioned on an equality that secures the same right to everyone gifted with the same ability.

\section{Why Liberalism Commits to the Promethean Idea}

If we assume that the interaction between society and its preconditions affects everyone's life but leave the transformation of the interaction into a mandetermined process (the Promethean venture) to some people only, we concede to them a privilege that for the reasons explained is incompatible with the liberal idea of rights. But there is an additional reason for rejecting this privilege. It even shows that the liberal idea of rights implies the Promethean idea.

Most liberals did not only assume a right to individual self-determination but also a duty to it, or at least recommended that individuals should master their life rather than being determined by the accidental conditions of their birth. This

\footnotetext{
${ }^{4}$ Locke defines rights (without using the term) when he defines the state of nature by the two properties of freedom and equality, justifying the latter by arguing that "nothing [is] more evident, than that Creatures of the same species and rank promiscuously born to all the advantages of Nature, and the use of the same faculties, should also be equal one amongst another without Subordination or Subjection". He implies that people's free use of their faculties is what their "Freedom" consists of, namely, that they can "order their Actions, and dispose of their Possessions, and Persons as they think fit, within the bounds of the Law of Nature, without asking leave, or depending upon the Will of any other Man" (Two Treatises of Government, II §4). So the decisions that liberty consists of are conditioned on everyone's equal claim to such decisions; it is not just liberty but everyone's equal liberty that he bases rights on. Similarly, Kant defines 'right' as 'the sum of the conditions under which the arbitrary will of anyone can be consistent with the arbitrary will of any other one under a universal principle of freedom" (Metaphysik der Sitten, Einleitung in die Rechtslehre $\S \mathrm{B}$ ). He also conditions liberty on equality.
} 
is why individual self-determination is rightly considered to be a positive leading idea of liberalism and modernity and not only a negative prohibiting principle. But most liberals did not sufficiently consider that people cannot decide on their own life without regard to how other people decide on their life. They emphasized that everyone has to respect the interest of other people in determining their life but have been rather blind to the more biological fact that we are all depending on natural resources and the necessarily social ways to use them. Our dependency on nature can be reduced by the Promethean venture. But our dependency on each other cannot be reduced; rather, it is enhanced by the Promethean venture. The more societies develop by division of labor and other ways by which mankind as a whole attains mastery of nature, the more individuals become dependent on each other. ${ }^{5}$

Therefore, the right of individuals to self-determination implies their right to their cooperative determination of the social conditions in which they use their natural environment. An individual's self-determination can never be isolated from other individuals' self-determination. Individual self-determination presupposes collective self-determination. But the collective self-determination is the Promethean venture. So, liberals cannot consistently favor individual selfdetermination without favoring the Promethean venture. Liberalism commits to the Promethean venture.

\section{The Anti-Economist Argument}

Let's come back to the question of whether unemployment is unjust even if the dole is decent. If we accept both the liberal idea of rights implying the equality condition and our dependence on the interaction of society with its preconditions, and if we accept that economy is part of this interaction process and unemployment excludes from this part of the process, then the conclusion is that involuntary unemployment is unjust even if compensated with a decent dole. I presume we accept the liberal idea of rights and our dependence on the interaction. We certainly have also to accept that economy is part of the interaction, understood as people's dependency on the preconditions of society. But is it also part of the interaction when the interaction is transformed into the Promethean venture?

If exclusion from economy means exclusion from the Promethean venture, the employed, in contrast to the unemployed, should codetermine the Promethean venture. At this expectation we may laugh. For it seems that as little as the unemployed, the mass of the employed take part in that venture. Even the leaders of economy whose decisions have an effect on the interaction do not really determine it, as we may argue. Rather, they are determined by the constraints of an economic system they are incapable of controlling because it depends on markets. In economy there just is no determination of society's interaction with nature, neither by the masses nor by the economic leaders. The unemployed are

\footnotetext{
5 This fact has been given most prominence to by Durkheim and, of course, Marx.
} 
not excluded from the Promethean venture because economy is excluded from this venture.

An argument of this kind has probably convinced Marx and other thinkers that mankind can never overcome its dependency on nature as long as it does not replace market economy with a production that responds directly to the commands of an institution that represents the will of mankind, and such a form of production would be politics or administration rather than economy. Let's call this the anti-economist argument. It is powerful and momentous, but only as long as we overlook that it depends on a conception of the Promethean venture that may seem natural but is not. Most often, the Promethean venture has been conceived the way it is presupposed in the anti-economist argument. It is because the acceptance of this argument proved disastrous that the Promethean ideas have fallen in discredit.

\section{The Centralist and the Autonomous Conceptions of the Promethean Venture}

I call the conception of the Promethean venture presupposed in the anti-economist argument centralist because it expects this venture to consist of a process organized by a group of individuals or an institution that represents mankind. The models for the way the Promethean venture is performed are the processes directed by the central nervous system in man and other higher animals and by the modern state that governs a territory as an administrative center. Characteristically, its most influential defender, Thomas Hobbes, described this institution as a man constituted by a multitude or even as a "Mortall God". ${ }^{6}$ Despite changes in their matter or constitution, man and the state can be identical subjects or agents of long lasting processes if, and only if, they follow identical decision procedures by which their will is established and executed. Such are rational deliberation in the case of man and institutional rules in the case of the state. Correspondingly, mankind can become the subject of the Promethean venture only if it is organized into a form in which it follows decision procedures that establish the will of mankind. Revolutionary groups that claim the right of acting in the name or for the sake of mankind follow this centralist conception of the Promethean venture.

The centralist conception cannot take account of the diversity of human interests and capabilities. Their diversity does not allow them to be unified in a set of decision procedures. If an institution or party claims it represents them, this can only result in stunting people's capabilities. This happened in the states that claimed to realize the Marxist version of the Promethean venture. The Promethean idea can only be defended if the centralist conception is replaced with one that respects the diversity of human activities and recognizes their specific, autonomous standards of right and wrong and perfection. Such a conception

\footnotetext{
${ }^{6}$ Hobbes 1968, 227, cp. 362. Hobbes also expressed his idea by choosing a title page for his edition that shows a crowned man above a territory whose body consists of a multitude of men.
} 
would accord to the multifarious human activities the capacity of changing from a dependent into a quasi mastery form not if they are organized by an identical subject but if they conform to their specific standards of perfection. Mankind would become Promethean not by subjecting itself to the decision procedure of one institution but by subjecting its diverse activities to their autonomous standards of perfection. What these standards are is not decided by an institution but the agents themselves. That is why I call the non-centralist conception autonomous.

Economic activities can serve as an example to illustrate both this autonomous conception and the prevailing centralist one. According to the centralist conception, economic activities can belong to the Promethean venture only if market production is replaced by a form that produces not for the unpredictable demands of the markets but for the recognized demands of the consumers. The demands are recognized in a decision procedure of the revolutionary institution-party, state or religion - that claims to represent the will of Promethean mankind. Market production necessarily is an arrogation of decisions that belong not to the agents of economy but to the representatives of mankind. Markets can never express the will of mankind as they are incompatible with a decision procedure of one institution.

According to the autonomous conception of the Promethean venture, economic activities, whether they use markets or not, become Promethean when the economic agents produce and exchange in a way they think perfect for achieving the specific aim of economic activities, which is the production of wealth or the perfect satisfaction of consumption interests. The autonomous conception presupposes that activities are distinguished by different aims that require different perfection standards. Their standards cannot be deduced from some abstract moral principles but must be learned by doing. Therefore, the agents of economy cannot delegate their decision and responsibility to any representatives of mankind. Rather, they themselves represent mankind in its effort to transform dependence in economy into mastery.

The same applies to other spheres of activities, for which the centralist conception of the Promethean venture has never been convincing. The scientist, the artist or the religious cannot delegate their decisions on what is right or wrong in their spheres to any representative of mankind. It is obviously up to them to decide which standards of right and wrong they should use. Had the adherents of the Promethean idea thought of science, arts, religion, the family and other spheres in which mankind is dependent and can become quasi master, the centralist conception would have seemed too weird to them. They succeeded to disregard them by considering them dependent on economy and presupposing that economy can be mastered only by politics or administration. But dependency in the spheres outside politics and economy has its specific causes, just as mastery in them has its autonomous standards irreducible to those of economy or politics. 


\section{Is the Autonomous Venture Still Promethean?}

True, the autonomous conception forces us to think of the Promethean venture in a way that may seem too new as to allow calling it Promethean. First, the idea of mankind's becoming master or quasi master of nature turns into the idea of detecting and applying the specific perfection standards. But rather than abolishing the Promethean idea, this change clarifies it. Becoming master of nature is no clear idea at all while detecting and applying perfection standards is, provided we look at spheres such as science or economy where we find unambiguous perfection standards. Moreover, replacing contingent moral standards by adequate perfection standards of value-spheres is an emancipation from history and nature that conforms precisely to the idea of a Promethean venture.

Second, the centralist conception presents the Promethean venture as one process fought by one subject, mankind, condensed into the avant-garde of a revolutionary party or religious community. ${ }^{7}$ The autonomous conception presents it as a process fought in the many spheres of activities that differ by their different perfection standards. It is split into as many processes as there are value spheres in the autonomous conception; hence, the idea that they belong together can be lost and with it the very idea of a Promethean venture. But it can be regained as soon as we remember that they all transform dependence on accidental moral standards into criteria that do justice to the kinds of activity we can perform. They all belong to a process of emancipation in which success or failure in one part affects any other part.

Moreover, the centralist conception fails the liberal participation condition, the autonomous conception does not. The centralist conception, though it appeals to everyone to join the fight of the avant-garde for progress, has in fact no place for everyone's participation; average people are downgraded to applaud the avant-garde. In contrast, though the autonomous conception allows for spherespecific avant-gardes, they are dependent not on the applause but the judgment of the average members of a sphere. Even the leading scientists are dependent on standards developed not by them but the community of science and their application by any member of the community. ${ }^{8}$

\section{The Autonomous Conception Does Not Exclude Regulation But Favors State Shrinkage}

Today, most economic agents reject the Marxist idea that market economy is doomed to be replaced with a form that will produce what has been decided in a political or another non-economic decision procedure. They argue that if a future society does without markets and still keeps the complex division of

\footnotetext{
7 Seyyid Qutb, one of the most influential thinkers of radical political Islam, thinks of radical Islamists as the "leadership of mankind" to be taken over from the "leadership of mankind by Western man" (1965, 10, 7)

8 I have been more explicit on perfection standards in Steinvorth 2009a in the chapters on value spheres.
} 
labor and feeds the billions of people living today, it will not be a society of abundance and liberty. By this argument they do not only reject the Marxist theory of economy but also the Marxist centralist conception of the Promethean venture. But their insistence on the necessity of markets for complex and free societies implies neither a defense of neo-liberal ideas of market deregulation nor a rejection of the Promethean idea. It is compatible with both insisting that market regulations are as necessary for flourishing societies as markets and with considering economic activities part of the Promethean venture. But it favors the shrinking of states to mere justice enforcement institutions, leaving their administrative tasks to the spheres they have been arrogated from. In this conception, it would belong to the task of the agents of economy to find out the regulations that have the most desirable effects and to the task of politics to watch over the regulations of the markets.

We may confirm the autonomous conception of the Promethean venture by an additional argument. Politics will never be capable of positively prescribing market regulations. It can only negatively prescribe what economy must not do. Its positive accomplishment must be left to economy. If people have a chance to realize their individual ideas of what one should produce, this helps produce what is good for production and mankind, provided markets are regulated by principles that exclude or minimize harmful products and production.

\section{A Non-Promethean Reason Why Involuntary Unemployment Is Unjust}

Let's again return to our starting question, whether unemployment is unjust even if compensated by a decent dole. Our discussion of the Promethean idea was to decide whether the sphere of economy that the unemployed are excluded from is part of the Promethean venture at all. The result is that it is as we must conceive of this process in the autonomous and not the centralist way. So if we accept the Promethean idea, as I said I presume we do in order to be consistent liberals, then we have to conclude that involuntary unemployment is injustice, even if it is compensated with a decent dole.

But there is another reason why involuntary unemployment is unjust. According to most theorists, the natural resources that are allocated in any economy are neither private property nor common property of a kind that would be free for use by those who come first. Rather, they are a commons that must be used in the interest of all mankind. ${ }^{9}$ Therefore, the unemployed are excluded from participation in the productive use of what is also their common property. This exclusion is an offence not only to their right of codetermining the Promethean venture but also to their common property. True, the employed have not much say in this codetermination. But they do have influence because they can put pressure on what happens in economy by strikes. The unemployed lack

\footnotetext{
${ }^{9}$ Locke has given this view classical expression by his so called proviso, stating that natural resources may be become private property only "where there is enough, and as good left in common for others" (Treatise II $\S 27$ ).
} 
this power. Hence, even if we reject the Promethean idea, we have an argument that involuntary unemployment is unjust: it is because it offends the right of the unemployed to participate in deciding on the use of what is also their common property. Despite its importance, I shall not look closer at this argument.

\section{How the Dole Might Abolish the Injustice of Unemployment}

Now, the result that involuntary unemployment is unjust even if the dole is decent will provoke doubts. Labor is unpleasant and often enough stultifying. So if I can have a decent life without labor, why should and how may I complain? The first answer is that without labor I'm excluded from that part of the Promethean venture that is performed in economy. Yet this answer provokes the next question: why should I insist on participating in this special part? If we conceive of the Promethean process in the autonomous way, there are other spheres of activities in which I might participate. Does not even the fact that I am unemployed prove that I lack the talent for economic activities and should be grateful for the chance to become active in another sphere, thanks to the decent dole?

In fact, if we conceive of the Promethean venture in the autonomous way, we cannot give priority to economy but must consider the transformation of any sphere of activities that pursues specific aims with specific values and standards of perfection as equally important in the Promethean venture. We have to agree that there is no injustice in my originally involuntary unemployment if the dole allows me to participate in other spheres for which I have a greater talent than for economy. But we have to add a proviso. My autonomy is offended if I lack the choice of participating in economy. The dole must have a form that secures me this choice if for whatever reasons I insist on participating there. How can it have such a form?

The dole would secure me the choice if it were converted into a basic income that is unconditionally paid to everyone and allows everyone the choice between a frugal life without employment and an employment that offers more money. ${ }^{10}$ Such a conversion would make unemployment attractive for a number of people and give a corresponding number among the unemployed a chance to find employment. There might be other conversions of the dole that have a similar effect. Moreover, if everyone had an opportunity for survival by labor without employment, for instance by tilling a field, there would be no injustice at all in unemployment. Only because the tilling solution would lead to the starvation of billions of people do we need to look for solutions that make use of the high productivity of modern societies that causes unemployment. So let us look at some objections to the introduction of basic income.

\footnotetext{
10 For information on basic income, cp. van Parijs 1995 and Pettit 2007.
} 


\section{Objections to the Basic Income}

The first objection is that basic income would make labor in the economic sphere so unattractive that too few people would remain in it. True, if even the lowest basic income that just ensures a decent life would leave too few people in economy, we can forget about it. But this is implausible, as the problems of unemployment arise just because the economy produces more than the consumers can buy with the money they have. Experts agree neither on how much can be paid as a basic income nor on the best way to introduce it. But even conservative politicians and established economists agree that a basic income that ensures a decent life and does not reduce production is possible. ${ }^{11}$ So we shouldn't be too skeptical of the argument that it is possible to balance out how low basic income and how high net salaries in business should be for having the desired effect of a flourishing economy.

Another objection is that it is unjust to tax the busy to finance the lazy. The answer is that technology has made the moral predications of industriousness and laziness obsolete. The industrious are today the people who arrogate the natural resources. They exclude the rest of mankind from common property. Natural resources have not been produced by those who exploit them; they are not their private property. So it is not unjust to tax the industrious. True, it would be both unjust and stupid to tax them so severely that they would stop producing. The wealth they produce is only to a part the result of their use of common property. Another part is their due. They have a right to be rewarded for their social function to make the economically most productive use of social resources and to be rewarded in proportion to the degree of their productivity. But society has also a right to siphon off from their product the value that is due to the resources that are common property. ${ }^{12}$

A third objection is that basic income will not make people active in the noneconomic value spheres but rather restrict their lives to fighting for increases of basic income. This danger ${ }^{13}$ can perhaps be reduced if activities in other spheres are rewarded by their sphere-specific forms of gratification and individuals learn to value such gratifications. For the artist and scientist, reward by money is less important than the recognition by those they esteem.

\footnotetext{
11 Cp., among many others, Straubhaar 2006.

12 The amount of this value cannot be measured by fixing the value of natural resources; for natural resources do no longer exist in their original form when no labor had been added to them. Steiner 1981; 1992 and 1994, 271, proposes that the "over-appropriators" of natural resources, in proportion to their over-appropriation, compensate the "under-appropriators". I think it is just impossible to evaluate in any currency over- and under-appropriation. Cp. Steinvorth 1999, 123-138, and Steinvorth 2009b. The value of the common resources can only be measured by the costs necessary for sustaining natural resources, including a healthy environment. Moreover, as far as people are excluded from using cultural resources by their lack of education, the costs of making this part of the common resources accessible to everyone by education also has to be financed by taxing those who are advantaged by their education.

13 This is the reason I criticised basic income in Steinvorth 1999, 161ff.
} 


\section{An Objection by Arendt}

Still, we may doubt if a sufficient number of people are capable of understanding the value and even meaning of activities outside the economic sphere. That they are not has been the thesis of Hannah Arendt and a reason for her expecting a bleak future. Commenting in the 1950s on the society we have to expect in the very near future, she called it "a society of laborers without labor, that is, without the only activity left to them. Surely, nothing could be worse." (Arendt $1958,5)$

Nothing could be better under conditions that we might call normal than that people become superfluous in economy and labor becomes scarce; labor is unpleasant. Yet according to Arendt, labor has become the only activity left to most people that gives them meaning, although it is an activity that 'normally' is only a necessary means for activities that have a meaning. The Greeks still knew that meaning is given to life by what Arendt calls action and work. Today, the horizon of experience has shrunk and it is only the activities of preserving life that we share with animals in which most people can find meaning. Therefore, nothing could be worse than the society we are living in, a society that runs short of labor. In such a society, basic income will not be the door to spheres of activity such as science and arts. Activities that do not serve life but have a life-independent meaning and make life worth living in the first place are not understood by most people. Hence, introducing basic income will only lead to fighting for its increase.

Perhaps Arendt is right. If she was, we would have little reason to think of abolishing the conditions that make unemployment unpleasant and unjust, let alone of the Promethean venture. The best we can make of her thesis is to insist on the life-independent value of activities in non-economic spheres, such as that of science and arts. But a necessary condition for developing an understanding for such activities is that people are no longer coerced to find a job to earn their money. Basic income would rid them of this coercion. It is certainly not sufficient for the redetection of the meaning of activities that are not labor, but it is necessary.

Whether Arendt is right or not, she confirms that it is paradoxical to proclaim a right to labor. But she also confirms that unemployment in modern society is injustice, as it excludes the unemployed from the only activity that is generally understood to be meaningful. Thus she confirms that unemployment cannot be made just by even a decent dole if it does not open, first, the understanding for the meaning of activities outside labor and employment and second, the participation in such activities. ${ }^{14}$

\footnotetext{
14 I have been more explicit on this and some other points only touched in this paper in Steinvorth 2009.
} 


\section{Conclusion}

There are risks in introducing basic income, but there are still more risks in not introducing it. It seems not too implausible that the coercion of labor can be got rid of without loss of wealth. If this is true there is little sense in proclaiming a right to work that is a right to employment. The proclamation of a right to work presupposes that it is unjust not to have an employment. Considering the resources of modern societies, it is difficult not to agree with this presupposition. But if (1) it is unjust not to have an employment, (2) the labor of employment is unpleasant for most people, (3) it is possible to do without unpleasant labor by introducing an institution such as basic income and (4) participation in the Promethean venture is possible without the coercion of labor, then it would be irrational not to introduce such an institution. Hence, rather than proclaiming a right to work we should proclaim a right to live without the coercion of labor but with the opportunity of participating in one or more of the branches of the Promethean venture. Participation in it is necessary because it is required by the liberal principle of equality.

\section{Bibliography}

Arendt, H. (1958), The Human Condition, Chicago

Aristotle (1999), Nicomachean Ethics, transl. and ed. by Terence Irwin, Indianapolis

Cicero (1991), On Duties, ed. M. T. Griffins and E. M. Atikins, Cambridge

Hobbes, T. (1968), Leviathan, ed. Macpherson, Harmondsworth

Hohfeld, W. N. (1919[1946]), Fundamental Legal Conceptions as Applied in Judicial Reasoning, Yale

Kant, I. (1954), Metaphysik der Sitten, ed. Vorländer, Hamburg

Locke, J. (1960), Two Treatises of Government, ed. Laslett, Cambridge

Marx, K. (1971), Das Kapital, Bd. 1, Berlin

Pettit, P. (2007), A Republican Right to Basic Income?, in: Basic Income Studies 2, $1-8$

Seyyid Q. (1965), Milestones, Damascus (Dar al-Ilm), n.d.

Steiner, H. (1981), Liberty and Equality, in: Political Studies 29, 555-569

- (1992), Three Just Taxes, in: P. van Parijs (ed.), Arguing for Basic Income, London, 81-92

- (1994), An Essay on Rights, Oxford

Steinvorth, U. (1999), Gleiche Freiheit, Berlin

- (2009a), Rethinking the Western Understanding of the Self, New York

- (2009b), Zwei Wurzeln der Allmendebewegungen, eine Politik, in: S. Helfrich (ed.), Gene, Bytes und Emissionen, München

Straubhaar, T. (2006), Grundeinkommen: Nachhaltigkeit für den Sozialstaat Deutschland, in: HWWI Update Mai 2006

Van Parijs, P. (1995), Real Freedom for All, Oxford 